\title{
Degradation of Proteins for Neural Cell Adhesion Patterning by Carbon Negative-Ion Implantation
}

\author{
Hiroshi Tsuji* ${ }^{1}$, Piyanuch Sommani ${ }^{2}$, Hiroko Sato ${ }^{1}$, Yasuhito Gotoh ${ }^{1}$, \\ Junzo Ishikawa ${ }^{3}$ and Gikan Takaoka ${ }^{2}$ \\ 1) Department of Electronic Science and Engineering, Kyoto University, \\ Fax: 81-075-383-2283, e-mail: tsuji@kuee.kyoto-u.ac.jp \\ ${ }^{2)}$ Photonics and Electronics Science and Engineering Center, Kyoto University \\ ${ }^{3)}$ Department of Electronics and Information Engineering, Chubu University
}

\begin{abstract}
Degradations of the adhesive proteins of gelatin (GEL), laminin (LN) and poly-D-lysine (PDL) on polystyrene (PS) by carbon negative-ion implantation for nerve-cell adhesion patterning were investigated. Solutions of adhesive proteins were in the concentration ranges of $5-1000,0.5-$ 50 and $0.5-33 \mathrm{~g} / \mathrm{ml}$ for GEL, LN and PDL, respectively. The ion implantation conditions were set at $10 \mathrm{keV}$ and fluences of $10^{14}-10^{16}$ ions $/ \mathrm{cm}^{2}$. Based on XPS analysis, the suitable protein concentrations for coating the pre-treated PS with $\mathrm{C}^{-}$-implantation at $10 \mathrm{keV}$ and $3 \times 10^{15}$ ions $/ \mathrm{cm}^{2}$ were in the ranges of $5-1000,2.5-50$ and $5-33 \mathrm{~g} / \mathrm{ml}$ for GEL, LN and PDL, respectively. After $\mathrm{C}^{-}$-implantation into the protein-coated PS with concentrations, amounts of proteins left on PS were evaluated by XPS. Amount of all proteins decreased with an increase in the ion fluence. After in vitro cell culture, the cell-adhesion patterns on the unimplanted regions of GEL-coated PS at $5 \mu \mathrm{g} / \mathrm{ml}$ and LN-coated PS at $2.5 \mu \mathrm{g} / \mathrm{ml}$ for rat adrenal pheochromocytoma cell $(\mathrm{PC} 12 \mathrm{~h})$ and that on the unimplanted region of PDL-coated PS at $5 \mu \mathrm{g} / \mathrm{ml}$ for rat embryonic brain cortex neuronal cells were obtained at ion implantation fluence of $10^{14}$ ions $/ \mathrm{cm}^{2}$.
\end{abstract}

Key words: Negative-ion implantation, protein degradation, cell-adhesion patterning, polystyrene, nerve cells

\section{INTRODUCTION}

Biocompatible improvements of polymeric surfaces for formation of artificial neuron network have been investigated by carbon negative-ion implantation [1-7] due to its good advantage of charge-up free [8-10]. In case of hydrophobic polymers such as polystyrene (PS) and silicone rubber (SR), improvement of cell-adhesion properties on areas modified by carbon negative-ion implantation due to the formation of hydrophilic oxygen functional groups such as $\mathrm{C}-\mathrm{O}(\mathrm{H})$ and $\mathrm{C}=\mathrm{O}$ on the ion-induced defects was reported [1-7]. In case of hydrophilic polymers such as poly-lactic-acid (PLA), degradation and improvement of the cell-adhesion properties on the modified areas depending on the ion implantation conditions were presented $[2-3,5]$. For both cases, changing of physical surface property by the ion implantation condition led to controllability of cell-adhesion property $[2,6]$. We had reported the suitable implantation condition for the nerve cell-adhesion patterning on the $\mathrm{C}^{-}$-implanted PS [6]. However, the obtained patterns of nerve cells on PS still were not good due to lack of cell adhesion on some areas of the implanted surface. This indicates the weakly adhesive force of cells on such areas. Generally, the cell adhesions relate to the suitable adsorption of adhesive proteins of an extracellular matrix (ECM), which prefer the hydrophilic surfaces [11]. In cell culture, ECM such as laminin, collagen including gelatin, fibronectin, vitronectin, etc. lies between the cell body and the surface and has an important function as 'footing' site for cell adhesion on the surface. Generally, they can be produced by cells and also are found in the serum-contained culture medium. However, the present of ECM sometimes is not enough for the cell requirement. In our previous work, we had reported the cell adhesion patterning on the adhesive proteins coated on $\mathrm{C}^{-}$-modified PS [7]. Although the cell-adhesion uniformity could be improved, the selective adhesion was degraded. Regarding to the physical surface change after ion implantation, changing in the cell-protein binding capability of proteins by using the carbon negative-ion implantation should be possible. Therefore, carbon negative-ion implantation into the surfaces pre-coated with adhesive protein or specific synthesis matrix should be possible to pattern cell adhesion.

In this present, the $\mathrm{C}^{-}$-implantation into PS surfaces pre-coated with proteins of gelatin, laminin and poly-D-lysine, to degrade the binding property between proteins and cells for patterning cell adhesion was investigated.

\section{EXPERIMENT}

Spin-coated polystyrene films on glass $(7 \%$ of polystyrene in toluene, PS Nacalai Tesque Inc., Japan) were used as a substrate. In case of the carbon negative-ion implantation, carbon negative ions were produced in a cesium sputter-type heavy negative-ion source (NIABNIS) [12-13] and the operating conditions for modification of polymeric surface have been given elsewhere [1-2].

In case of protein patterning, solutions of gelatin 
(GEL, G1890, Sigmal-aldrich Inc), laminin (LN, L2020, Sigmal-aldrich Inc.), and poly-D-lysine (PDL, P0899, Sigma-aldrich, Inc.) were in the concentration ranges of $0.5-1,000 \mu \mathrm{g} / \mathrm{ml}$. The samples were immersed into these proteins for $1-2 \mathrm{~h}$ at $37^{\circ} \mathrm{C}$ and were rinsed by distilled water for 2-3 times before drying for $30 \mathrm{~min}$. Firstly, the suitable protein concentrations for coating were evaluated. PS was implanted at $10 \mathrm{keV}$ and $3 \times 10^{15}$ ions $/ \mathrm{cm}^{2}$ as a half moon shape, and samples were coated with these protein concentrations. The adsorption properties were evaluated by detecting nitrogen atoms with using XPS analysis (AXIS-165s, Shimadzu). XPS narrow spectra of nitrogen atoms on both regions were measured with the X-ray sources of monochromatic $\mathrm{AlK} \alpha(1486.6 \mathrm{eV})$ and non-monochromatic $\mathrm{MgK} \alpha$ $(1253.6 \mathrm{eV})$ at a relatively weak intensity to avoid modifying the surface state by irradiation. After obtaining the suitable concentration, confirmation of protein degradation on PS was then investigated. PS surfaces were immersed into the obtained concentrations and were degraded with $\mathrm{C}^{-}$-implantation at $10 \mathrm{keV}$ and fluences of $10^{14}-10^{16}$ ions $/ \mathrm{cm}^{2}$ as a half moon shape. XPS analysis was again used to evaluate the degradation ratios of proteins from decreasing of nitrogen amounts between both regions. XPS narrow spectra of carbon, nitrogen and oxygen on both regions were investigated.

In case of cell-adhesion patterning on the $\mathrm{C}^{-}$-modified protein layers, the protein-coated PS surfaces were patterned at $10 \mathrm{keV}$ and fluences of $10^{14}$ $10^{16}$ ions $/ \mathrm{cm}^{2}$ with using a micro-pattern mask, which consists of many slit apertures with $50-\mu \mathrm{m}$ width and $70-\mu \mathrm{m}$ spacing. The samples were sterilized by using ultra violet light for $4 \mathrm{~h}$ and were set into a $35-\mathrm{mm}$ dish (Non-treated polystyrene dish, Corning). For samples coated with GEL and LN, nerve-like cells of rat adrenal pheochromocytoma (PC12h) with about $2.5 \times 10^{5}$ cells $/ \mathrm{ml}$ were cultured on the sample dishes in Dulbecco's modified Eagle's medium (DMEM, Nissui, Japan) containing $5 \%$ heat-inactivated horse serum (HS, Biomedicals, USA) and 5\% fetal bovine serum (FBS, Bio-Wittker, USA), sodium hydrogen carbonate (1.8 $\mathrm{mg} / \mathrm{ml}$, Wako, Japan) with antibiotic of penicillin $\mathrm{G}$ and streptomycin for 2 days under $5 \% \mathrm{CO}_{2}$ at $37^{\circ} \mathrm{C}$ in incubator. For samples coated with PDL, rat brain cortex neuronal cells (R-Cx-500, Cambrex Bioscience Walkersville Inc.) with about $4 \times 10^{5}$ cells $/ \mathrm{ml}$ were cultured on the sample dishes in serum-free neurobasal medium (N-medium, 12348-017, Gibco) containing 2\% B-27 supplement (B27, 17504-044, Gibco) for 23 days. The cell-adhesion properties on each $\mathrm{C}^{-}$-modified protein layers were observed by phase contrast microscope (CK2, Olympus).

\section{RESULTS AND DISCUSSION}

3.1 Protein concentration for uniform layer by XPS

Based on XPS analysis, amounts of nitrogen adsorption on the implanted regions of $\mathrm{C}^{-}$-implanted PS at $10 \mathrm{keV}$ and $3 \times 10^{15}$ ions $/ \mathrm{cm}^{2}$ as a function of protein concentration are shown in Fig. 1, where (a) gelatin-coated PS (GEL/PS), (b) laminin-coated PS (LN/PS) and (c) poly-D-lysine-coated PS (PDL/PS).

Amount of nitrogen adsorption increased from 2490 to 9300 for GEL concentration range of $5-100 \mu \mathrm{g} / \mathrm{ml}$ (Fig. 1(a)), from 560 to 11800 for $\mathrm{LN}$ concentration range of $0.5-2.5 \mu \mathrm{g} / \mathrm{ml}$ (Fig. 1(b)), and from 1130 to 3010 for PDL concentration range of $0.5-5 \mu \mathrm{g} / \mathrm{ml}$ (Fig. 1(c)) before saturation. For GEL, the amounts of nitrogen adsorption from the nitrogen atoms in the amino acid with their error of all concentrations were very large. The large error may be due to the adhesive force between the amino acids $(\mathrm{N}-\mathrm{H})$ of GEL and the hydrophilic bonds $(\mathrm{C}-\mathrm{O}(\mathrm{H})$ and $\mathrm{C}=\mathrm{O})$ of $\mathrm{C}^{-}$-implanted PS. GEL is obtained from the deterioration of collagen, which has many hydrophilic-types of amino acids. Thus, the amino acids of gelatin look-like that of collagen with different adhesive force. The adhesive force between amino acid bonds and surface comes from the hydrogen bond that is easily destroyed by water force [14]. That means too large amount of nitrogen adsorption in someplace makes the detachment easily to happen. These resulted in the large error of GEL. For LN and PDL, the amounts of nitrogen adsorptions on hydrophilic PS were also good for all concentrations, excepting at low concentration that the large error occurred. This might be due to insufficient concentration to adsorb on the surface.

From observation, the protein concentration for uniform coating should be in the ranges of $5-1000,2.5$ -50 , and $5-33 \mu \mathrm{g} / \mathrm{ml}$, respectively. Then, the concentrations for study of degradation protein with $\mathrm{C}^{-}$-implantation were selected at $1000,2.5$ and $10 \mu \mathrm{g} / \mathrm{ml}$, for GEL, LN and PDL, respectively.

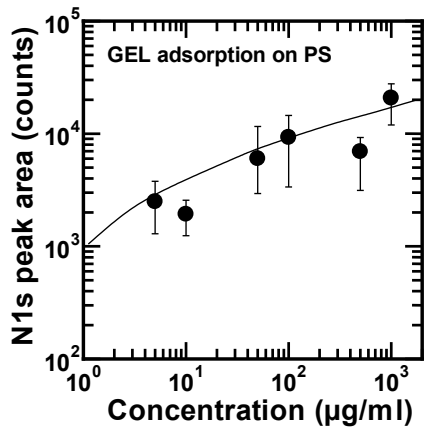

(a) GEL/PS

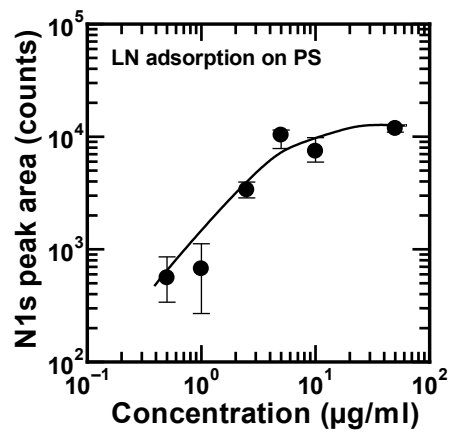

(b) LN/PS

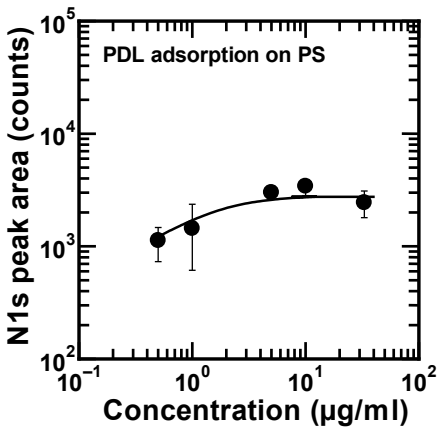

(c) PDL/PS

Fig. 1. Amounts of nitrogen adsorption on hydrophilic PS treated by $\mathrm{C}^{-}$-implantation as a function of protein concentrations: (a) gelatin-coated PS (GEL/PS); (b) laminin-coated PS (LN/PS); and (c) poly-D-lysine-coated PS (PDL/PS). 


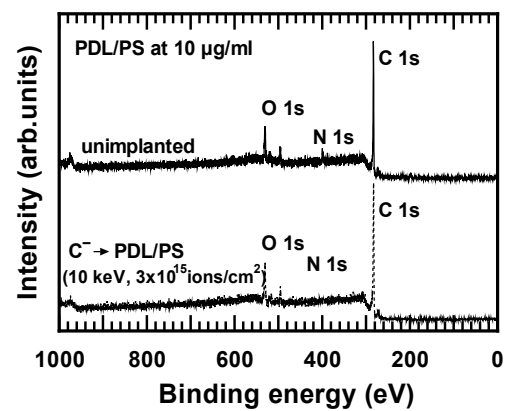

(a) survey

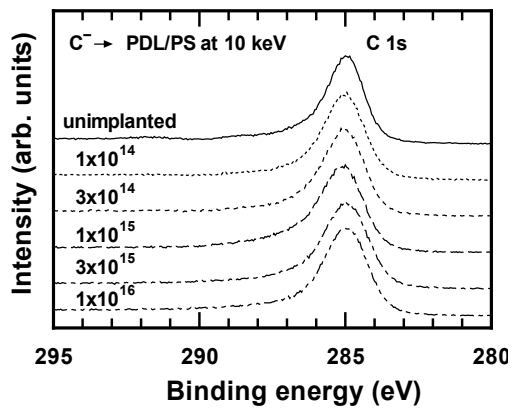

(b) $\mathrm{C} 1 \mathrm{~s}$ narrow

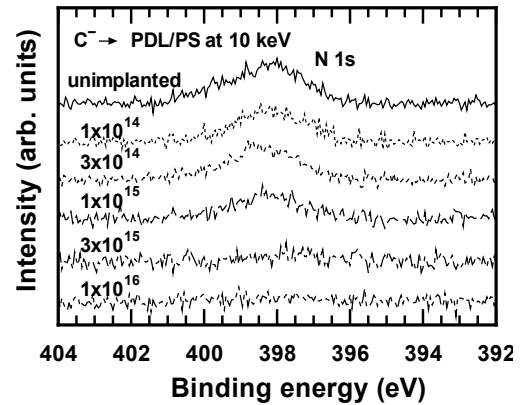

(c) N1s narrow

Fig. 2. XPS spectra on the unimplanted and implanted regions of the $\mathrm{C}^{-}$-implanted PDL/PS at coating concentration of $10 \mu \mathrm{g} / \mathrm{ml}$ and ion implantation energy of $10 \mathrm{keV}$ : (a) survey; (b) C1s narrow; and (c) N1s narrow.

\subsection{Amount of $\mathrm{C}^{-}$-degraded protein by XPS}

XPS spectra on the unimplanted and implanted regions of the $\mathrm{C}^{-}$-implanted surface of PDL-coated PS $\left(\mathrm{C}^{-}\right.$-implanted PDL/PS) at concentration of $10 \mu \mathrm{g} / \mathrm{ml}$ and ion energy of $10 \mathrm{keV}$ are shown in Fig. 2, where (a) survey; (b) C1s narrow; and (c) N1s narrow. In Fig. 2(a), peak of N1s appeared in XPS survey spectra from PDL adsorption, and it disappeared after the ion implantation at $3 \times 10^{15}$ ions $/ \mathrm{cm}^{2}$. With an increase in ion fluence, carbon intensity increased with having a longer tail on the left side as shown in Fig. 2(b), while the nitrogen intensity decreased as shown in Fig. 2(c). The increases of carbon intensity and oxygen intensity (data not shown) were due to the doping atoms and the formation of oxygen functional groups of $\mathrm{C}-\mathrm{O}(\mathrm{H})$ and $\mathrm{C}=\mathrm{O}$ on the ion-induced defects, respectively. These may change the cell-binding capability of protein. Then, the degradation was evaluated from the amount of nitrogen left after the ion implantation.

Based on calculation of $\mathrm{N}$ peak areas, degradation ratios of nitrogen atoms between the implanted and unimplanted regions of protein-coated PS as a function of ion fluence are shown in Fig. 3, where (a) gelatincoated PS (GEL/PS) at $1 \mathrm{mg} / \mathrm{ml}$; (b) laminin-coated PS (LN/PS) at $2.5 \mu \mathrm{g} / \mathrm{ml}$ and (c) poly-D-lysine-coated PS (PDL/PS) at $10 \mu \mathrm{g} / \mathrm{ml}$. Degradation ratios of these three proteins were almost no different. With an increase in ion fluence from $10^{14}$ to $10^{16}$ ions $/ \mathrm{cm}^{2}$, the ratios decreased from 0.84 to 0.22 for GEL, from 0.74 to 0.09 for LN, and from 0.69 to 0.21 for PDL. In case of GEL, the errors for all ion implantation fluences were very large. These might be due to non-uniform coating that relating to the GEL structure. When considering about GEL structure as a network of fibers due to deformation of collagen structure, it is better to select low concentration to avoid an excess amount and non-uniform adsorption.

Therefore, the considerably suitable concentrations of GEL, LN and PDL to pre-coat PS surface before ion implantation for patterning cell adhesion should be 5 , 2.5 and $5 \mu \mathrm{g} / \mathrm{ml}$, respectively.

3.3 Nerve-cell adhesion patterning on degraded protein

Fig. 4 shows phase contrast micrographs of nerve-cell patterns on each $\mathrm{C}^{-}$-modified protein/PS at $10 \mathrm{keV}$ and $1 \times 10^{14}$ ions $/ \mathrm{cm}^{2}$, where (a) PC12h cells on GEL at $5 \mu \mathrm{g} / \mathrm{ml}$; (b) PC12h cells on $\mathrm{LN}$ at $2.5 \mu \mathrm{g} / \mathrm{ml}$; and (c) rat brain cortex neuronal cells on PDL at $5 \mu \mathrm{g} / \mathrm{ml}$. In case of $\mathrm{PC} 12 \mathrm{~h}$ cells, the cell-adhesion patterns were found on the non-implanted region only at low fluence of $10^{14}$ ions $/ \mathrm{cm}^{2}$ for coating with GEL and LN after 2 days culture as shown in Figs. 4(a) and 4(b), respectively. In case of rat brain cortex neuronal cells, the adhesion pattern was also found on the non-implanted region of PDL-coated PS at low fluence of $10^{14}$ ions $/ \mathrm{cm}^{2}$ after 16 days culture as shown in Fig. 4(c). At higher fluence, there were adhesions of PC12h cells on the implanted region instead, but no adhesion of rat brain cortex neuronal cells on any region. In case of $\mathrm{PC} 12 \mathrm{~h}$ cells, adhesion on non-implanted region at low fluence is considered to be due to sputtering effect on the ion implantation that resulted in the degradation of binding capability of the coated protein. While at higher fluence, not only the sputtering effect occurred, but also the

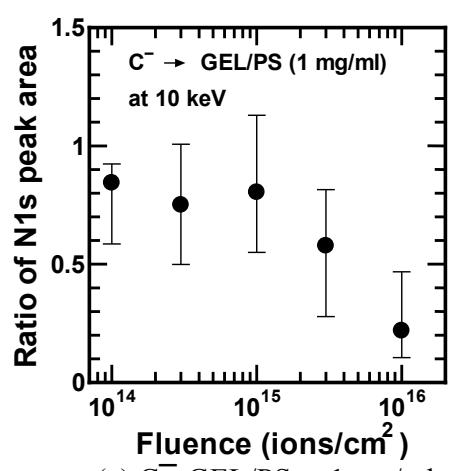

(a) $\mathrm{C}^{-}$-GEL/PS at $1 \mathrm{mg} / \mathrm{ml}$

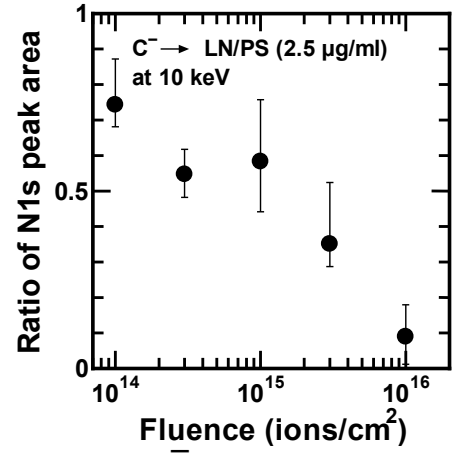

(b) $\mathrm{C}^{-}$-LN/PS at $2.5 \mu \mathrm{g} / \mathrm{ml}$

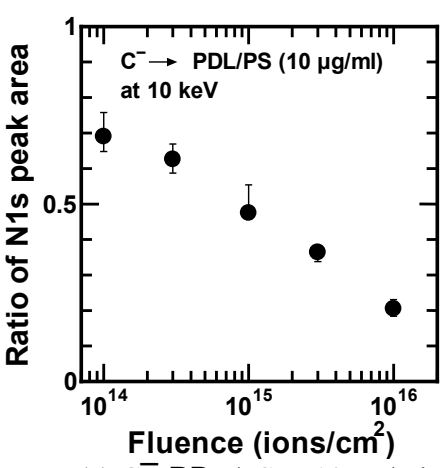

(c) $\mathrm{C}^{-}$-PDL/PS at $10 \mu \mathrm{g} / \mathrm{ml}$

Fig. 3. Degradation ratios of nitrogen atoms between the implanted and unimplanted regions of protein-coated PS as a function of ion fluence: (a) gelatin-coated PS (GEL/PS) at $1 \mathrm{mg} / \mathrm{ml}$; (b) laminin-coated PS (LN/PS) at $2.5 \mu \mathrm{g} / \mathrm{ml}$; and (c) poly-D-lysine-coated PS (PDL/PS) at $10 \mu \mathrm{g} / \mathrm{ml}$. 


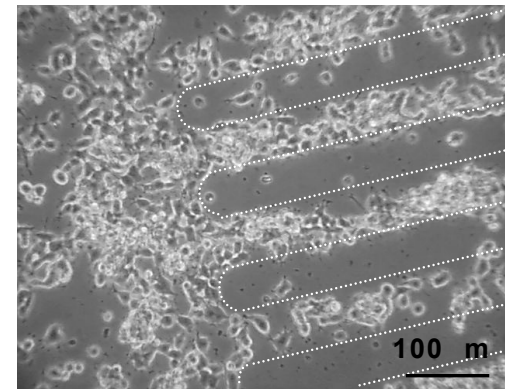

(a) PC12h cells on $\mathrm{C}^{-}$-GEL/PS

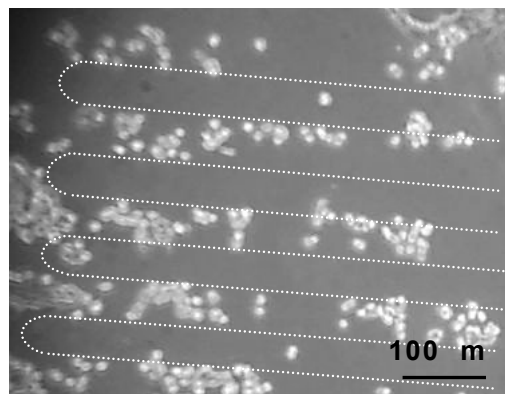

(b) $\mathrm{PC} 12 \mathrm{~h}$ cells on $\mathrm{C}^{-}-\mathrm{LN} / \mathrm{SR}$

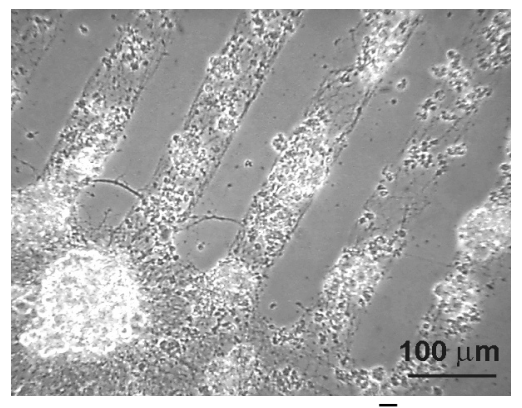

(c) cortex neuronal cells on $\mathrm{C}^{-}$-PDL/PS Fig. 4. Phase contrast micrographs of nerve-cell patterns on each $\mathrm{C}^{-}$-modified protein/PS at $10 \mathrm{keV}$ and $1 \times 10^{14}$ ions $/ \mathrm{cm}^{2}$ : (a) PC12h cells on GEL at $5 \mu \mathrm{g} / \mathrm{ml}$; (b) PC12h cells on $\mathrm{LN}$ at $2.5 \mu \mathrm{g} / \mathrm{ml}$; and (c) rat brain cortex neuronal cells on PDL at $5 \mu \mathrm{g} / \mathrm{ml}$.

formation of hydrophilic oxygen functional groups. These resulted in re-adsorption of proteins from serum on the implanted region, leading to PC12 cell adhesion. In case of rat brain cortex neuronal cells, adhesion on non-implanted region at low fluence is also considered to be due to sputtering effect on the ion implantation that destroyed PDL structure resulting in the degradation of cell- binding capability of PDL. Then, the cells could adhere only on the non-implanted region. At higher fluence, not only the sputtering effect occurred, but also the formation of hydrophilic oxygen functional groups. The sputtering effect increased with an increase in the ion fluence. Such sputtering particles or emitted gases from the implanted region could be adsorbed on the non-implanted region. This phenomenon also affected to the cell adhesion on the non-implanted region. The brain cortex neuronal cells can not adhere on the surfaces containing normal oxygen functional groups (negativecharge sites). Then, there was no adhesion of rat brain cortex neuronal cells on both regions.

From all investigations, the suitable conditions for patterning nerve-cell adhesion by using carbon negative-ion implantation to degrade cell-binding capability of proteins were at implantations of $10 \mathrm{keV}$ and $1 \times 10^{14}$ ions $/ \mathrm{cm}^{2}$ with concentrations of GEL, LN and PDL at 5, 2.5 and $5 \mu \mathrm{g} / \mathrm{ml}$ respectively.

\section{CONCLUSION}

Degradation of cell-binding capability of adhesive proteins such as gelatin (GEL), laminin (LN) and poly-D-lysine (PDL) by carbon negative-ion implantation for pattering nerve-cell adhesion were investigated. Based on XPS analysis, the suitable protein concentrations to obtain the good adsorption properties on polystyrene (PS) for gelatin, laminin and PDL were in the ranges of 5 $1000,2.5-50$, and $5-33 \mu \mathrm{g} / \mathrm{ml}$, respectively. For change of atomic bonding state on coated-surface, the carbon negative-ion implantation into the protein-coated PS with GEL at $1000 \mu \mathrm{g} / \mathrm{ml}$, LN at $2.5 \mu \mathrm{g} / \mathrm{ml}$ and PDL at $10 \mu \mathrm{g} / \mathrm{ml}$ showed the degradation of protein by changing in atomic compositions, especially nitrogen. Amount of nitrogen decreased from about 0.84 to 0.09 with an increase in the ion fluence from $10^{14}$ to $10^{16}$ ions $/ \mathrm{cm}^{2}$. For cell-adhesion patterning, $\mathrm{PC} 12 \mathrm{~h}$ cells adhered on the non-implanted regions of protein-coated PS with GEL at $5 \mu \mathrm{g} / \mathrm{ml}$ and $\mathrm{LN}$ at $2.5 \mu \mathrm{g} / \mathrm{ml}$, and rat brain cortex neuronal cells also adhered on that of PDL-coated PS at $5 \mu \mathrm{g} / \mathrm{ml}$ when implantation at low fluence of $10^{14}$ ions $/ \mathrm{cm}^{2}$. By using carbon negative-ion implantation into protein-coated PS, we achieved the pattern of the degraded protein for improvement of nerve-cell adhesion with patterning.

\section{REFERENCES}

[1] H. Tsuji, H. Sato, T. Baba, S. Ikemura, Y. Gotoh, and J. Ishikawa, Nucl. Instr. and Meth., B 166/167, 815-19 (2000).

[2] H. Tsuji, H. Sasaki, H. Sato, Y. Gotoh, and J. Ishikawa, Nucl. Instr. Meth., B 191, 815-19 (2002).

[3] H. Tsuji, H. Sasaki, Y. Utsumi, H. Sato, Y. Gotoh, and J. Ishikawa, Surf. Coat. Tech., 158-159, 620-23 (2002).

[4] H. Tsuji, M. Izukawa, Y. Utakawa, R. Ikeguchi, R. Kakinoki, H. Sato, Y. Gotoh, and J. Ishikawa, Trans. Mater. Res. Soc. Japan, 29 [2], 575-80 (2004).

[5] Tsuji, P. Sommani, T. Muto, Y. Utagawa, S. Sakai, H. Sato, Y. Gotoh, and J. Ishikawa, Nucl. Instr. and Meth., B 237, 459-64 (2005).

[6] P. Sommani, H. Tsuji, H. Sato, M. Hattori, T. Yamda, Y. Gotoh and J. Ishikawa, Trans. Mater. Res. Soc. of Japan, 31 [3], 673-76 (2006).

[7] T. Yamada, H. Tsuji, M. Hattori, P. Sommani, H. Sato, Y. Gotoh and J. Ishikawa, J. Vac. Soc. Jpn., 50 [9], 579-82 (2007).

[8] H. Tsuji, Y. Toyota, J. Ishikawa, S. Sakai, Y. Okayama, and S. Nagumo, "Ion Implantation Technology-94", Eds. by S. Coffa, G. Ferla, and R. Priole, Elsevier, New York (1995) pp. 612-15.

[9] H. Tsuji, J. Ishikawa, S. Ikeda, and Y. Gotoh, Nucl. Instr. and Meth., B 127/128, 278-81 (1997).

[10] H. Tsuji, Y. Gotoh, and J. Ishikawa, Nucl. Instr. and Meth., B 141, 645-51 (1998).

[11] Y. Ikeda ed., "Fundamental \& Application of Polymer Surfaces vol. 2", Kagaku Dozin co., ltd., Japan, (1998) p. 186.

[12] J. Ishikawa and H. Tsuji, Nucl. Instr. and Meth., B 74, 118-22 (1993).

[13] H. Tsuji, T. Taya, J. Ishikawa, and T. Takagi, "Proceedings of the International Ion Engineering Congress, ISIAT'83 \& IPAT'83", Vol. 1, Ed. by T. Takagi, Institute of Electrical Engineers of Japan, Kyoto (1983) pp. 141-46.

[14] CL. Rose and D.W. von Endt, eds., "Protein Chemistry for Conservators", American institute for Conservation of Historic and Artistic Works, Washington, D.C, (1984) p. 5. 